\title{
Trichocyalides A and B, new inhibitors of alkaline phosphatase activity in bone morphogenetic protein-stimulated myoblasts, produced by Trichoderma sp. FKI-5513
}

\author{
Takashi Fukuda $^{1,2}$, Ryuji Uchida ${ }^{1}$, Satoshi Ohte ${ }^{3}$, Hiroyo Inoue ${ }^{1}$, Hiroyuki Yamazaki ${ }^{1}$, Daisuke Matsuda ${ }^{1}$, \\ Kenichi Nonaka ${ }^{2}$, Rokurou Masuma ${ }^{2}$, Takenobu Katagiri ${ }^{3}$ and Hiroshi Tomoda ${ }^{1}$
}

Two new butenolides, designated trichocyalides $\mathrm{A}$ and $\mathrm{B}$, were isolated along with the known compound harzianolide, from the culture broth of Trichoderma sp. FKI-5513 by solvent extraction, ODS column chromatography and HPLC. Their structures were elucidated by several spectral analyses, showing that they have the common skeleton of butenofuranone. Trichocyalides $\mathrm{A}$ and $B$ inhibited alkaline phosphatase (ALP) activity, a typical marker enzyme of osteoblastic differentiation (IC ${ }_{50}: 83.0$ and $187 \mu \mathrm{M}$, respectively), in bone morphogenetic protein (BMP)-stimulated C2C12 myoblasts mutant cells, which stably express BMP receptor activity, whereas harzianolide showed no inhibitory activity against ALP even at $500 \mu \mathrm{M}$.

The Journal of Antibiotics (2012) 65, 565-569; doi:10.1038/ja.2012.70; published online 5 September 2012

Keywords: bone morphogenetic protein signaling; $\mathrm{C} 2 \mathrm{C} 12$ myoblasts; fibrodysplasia ossificans progressiva; trichocyalide; Trichoderma sp. FKI-5513

\section{INTRODUCTION}

Bone morphogenetic proteins (BMPs), members of the transforming growth factor- $\beta$ superfamily, are active proteins responsible for ectopic bone formation. ${ }^{1,2}$ The BMP signal starts with binding to heterotetrameric transmembrane complexes of type I and type II BMP receptors. Four type I receptors, ALK1, ALK2, ALK3/BMPR-IA and ALK6/BMPR-IB, and three type II receptors, BMPR-II, ActR-II and ActR-IIB, have been reported. ${ }^{3}$ Following ligand binding, serines and threonines in the glycine/serine domain of type I receptor are phosphorylated by the activated type II receptor. Thus, the activated BMP type I receptor transmits downstream to BMP pathway-specific Smad1/5/8 and p38 MAPK. ${ }^{4}$ Furthermore, phosphorylated Smad1/5/8 forms complexes with Smad4, and they move to the nucleus and work as transcription factors to express early responsive genes, such as Id1 (an inhibitory protein for myogenesis). ${ }^{4}$

Fibrodysplasia ossificans progressiva (FOP) is a congenital disorder of progressive and widespread postnatal ossification of soft tissues. ${ }^{5}$ Patients with classical FOP have congenital malformations that result in profoundly decreased mobility. ${ }^{6,7}$ Recently, a recurrent heterozygous mutation in the ACVR1/ALK2 gene was identified by Shore et al. ${ }^{8}$ at $617 \mathrm{G} \rightarrow \mathrm{A}$, which causes an amino acid substitution of Arg to His at codon $206(\mathrm{R} 206 \mathrm{H})$ of the ALK2 receptor in both familial and sporadic patients with FOP. Because this mutation induced the activation of BMP constitutively, BMP inhibitors could offer therapeutic benefits for FOP. ${ }^{4,9}$ In 1994, Katagiri et al. ${ }^{10}$ reported that $\mathrm{C} 2 \mathrm{C} 12$ myoblasts, derived from murine thigh muscle, expressed an osteogenic phenotype in the presence of high concentrations of recombinant BMP and that alkaline phosphatase (ALP) activity was induced by BMP in the clonal myoblasts; therefore, ALP activity was used as a typical marker of BMP signaling in the $\mathrm{C} 2 \mathrm{C} 12$ cell line.

Based on these findings, we established the screening method by using a stable ALK2(R206H)-expressing C2C12 cell line (abbreviated as $\mathrm{C} 2 \mathrm{C} 12(\mathrm{R} 206 \mathrm{H})$ cells). ${ }^{11}$ With this method, inhibitors of BMPinduced ALP activity in $\mathrm{C} 2 \mathrm{C} 12(\mathrm{R} 206 \mathrm{H})$ cells were screened as potential osteoblastic differentiation inhibitors. During the course of this screening program, we reported pyrrolidine-containing compounds ${ }^{12-14}$ produced by fungal strain Fusarium sp. B88 as candidates for osteoblastic differentiation inhibitors. ${ }^{11}$ Continuing this screening, two new active butenolides, designated trichocyalides A and B, were isolated from the culture broth of fungal strain Trichoderma sp. FKI-5513 along with the known harzianolide (Figure 1). ${ }^{15}$

In this study, we describe the taxonomy of the producing fungus, fermentation, isolation, structure elucidation and biological activity of these trichocyalides.

${ }^{1}$ Graduate School of Pharmaceutical Sciences, Kitasato University, Tokyo, Japan; ${ }^{2}$ Kitasato Institute for Life Sciences, Kitasato University, Tokyo, Japan and ${ }^{3}$ Research Center for Genomic Medicine, Saitama Medical University, Saitama, Japan

Correspondence: Professor H Tomoda, Graduate School of Pharmaceutical Sciences, Kitasato University, 5-9-1 Shirokane, Minato-ku, Tokyo 108-8641, Japan.

E-mail: tomodah@pharm.kitasato-u.ac.jp

Received 3 February 2012; revised 30 July 2012; accepted 30 July 2012; published online 5 September 2012 


\section{RESULTS}

\section{Taxonomy}

Colonies on potato dextrose agar after 7 days at $25^{\circ} \mathrm{C}$ (Figure 2a) were $>80 \mathrm{~mm}$ in radius, floccose, flat, with white (a) aerial mycelium, covered with moss green ( $24 \mathrm{pi}$ ) conidia, exudate lacking, soluble pigment not produced. Colonies on corn meal dextrose agar after 7 days at $25^{\circ} \mathrm{C}$ were $61-62 \mathrm{~mm}$ in radius and the surface showed hyaline floccose aerial mycelium. Colonies on synthetic low-nutrient agar after 7 days at $25^{\circ} \mathrm{C}$ (Figure 2b) were $53-55 \mathrm{~mm}$ in radius, floccose, flat, with hyaline aerial mycelium and covered with hunter green $\left(22 \mathrm{pi}\right.$ ) conidia. Colonies on potato dextrose agar at $5{ }^{\circ} \mathrm{C}$ and $37^{\circ} \mathrm{C}$ were not observed. Conidiophores were highly uniformly branched, branches frequently paired or in threes, arising at or near $90^{\circ}$ with respect to the main axis, longer and more profusely branched with distance from the tip (Figure 2c). The phialides arose singly from the main axis and branches or were held at or near $90^{\circ}$ in whorls, tending to be conspicuously swollen below the sharply constricted tip, ampulliform, $5.2-10.8 \mu \mathrm{m}$ long, $2.6-4.1 \mu \mathrm{m}$ at the widest point, 1.4-2.4 $(-3.0) \mu \mathrm{m}$ at the base. Conidia were ellipsoidal, $5.0-7.2(-7.8) \times 2.3-3.8 \mu \mathrm{m}$. The total length of the rDNA internal transcribed spacer (ITS; including $5.8 \mathrm{~S}$ rDNA) of FKI-5513 was 572 base pairs. From these findings, the producing strain FKI-5513 was considered to belong to the genus Trichoderma.

\section{Fermentation}

A slant culture of strain FKI-5513 grown on LcA medium $(0.1 \%$ glycerol, $0.08 \% \quad \mathrm{KH}_{2} \mathrm{PO}_{4}, \quad 0.02 \% \quad \mathrm{~K}_{2} \mathrm{HPO}_{4}, \quad 0.02 \% \quad \mathrm{MgSO}_{4} \bullet 7 \mathrm{H}_{2} \mathrm{O}$, $0.02 \% \mathrm{KCl}, 0.2 \% \mathrm{NaNO}_{3}, 0.02 \%$ yeast extract and $1.5 \%$ agar, $\mathrm{pH}$ 6.0) was used to inoculate $100 \mathrm{ml}$ seed medium (2.0\% glucose, $0.2 \%$ yeast extract, $0.05 \% \mathrm{MgSO}_{4} \bullet 7 \mathrm{H}_{2} \mathrm{O}, 0.5 \%$ polypeptone, $0.1 \%$ $\mathrm{KH}_{2} \mathrm{PO}_{4}$ and $0.1 \%$ agar, $\mathrm{pH} 6.0$ ) contained in a 500 -ml Erlenmeyer flask. The flask was shaken on a rotary shaker at $27^{\circ} \mathrm{C}$ for 3 days. The seed culture $(1 \mathrm{ml})$ was used to inoculate a $500-\mathrm{ml}$ Erlenmeyer flask containing $100 \mathrm{ml}$ production medium $(3.0 \%$ soluble starch, $1.0 \%$<smiles>[R]CC1C(=O)OCC1C=CC=CC</smiles>

Trichocyalide A R: - $\mathrm{OH}$

Harzianolide $\mathrm{R}:-\mathrm{CH}(\mathrm{OH}) \mathrm{CH}_{3}$ glycerol, $2.0 \%$ soy bean meal, $0.3 \%$ dry yeast, $0.3 \% \mathrm{KCl}, 0.2 \% \mathrm{CaCO}_{3}$, $0.05 \% \mathrm{KH}_{2} \mathrm{PO}_{4}$ and $0.5 \% \mathrm{MgSO}_{4} \cdot 7 \mathrm{H}_{2} \mathrm{O}$ ). The fermentation was carried out at $27^{\circ} \mathrm{C}$ for 7 days.

\section{Isolation}

The 7-day-old culture broth (4.01) was extracted with 4.01 acetone. After the acetone extracts were filtered and concentrated, the resulting aqueous solution was extracted with EtOAc (4.01). The ethyl acetate layer was dried over $\mathrm{Na}_{2} \mathrm{SO}_{4}$ and concentrated in vacuo to dryness to yield a yellow brown material $(2.0 \mathrm{~g})$. The material was dissolved in $30 \% \mathrm{CH}_{3} \mathrm{CN}$, applied to an octa decyl silyl (ODS) column (30 g), and eluted stepwise with $30,50,70$ and $100 \% \mathrm{CH}_{3} \mathrm{CN}$ (300 ml for each two fractions). The second $30 \% \mathrm{CH}_{3} \mathrm{CN}$ fraction was concentrated in vacuo to dryness to give a brown material (113 mg). The material was finally purified by preparative HPLC (column, PEGASIL ODS, $20 \times 250 \mathrm{~mm}$; Senshu Scientific Co. (Tokyo, Japan); solvent, $35 \%$ $\mathrm{CH}_{3} \mathrm{CN}$; detection, $\mathrm{UV}$ at $210 \mathrm{~nm}$; flow rate, $8.0 \mathrm{ml} \mathrm{min}{ }^{-1}$ ). Under these conditions, trichocyalide A was eluted as a peak with a retention time of $27 \mathrm{~min}$. The pooled fraction was concentrated in vacuo to dryness to give pure trichocyalide A $(3.6 \mathrm{mg})$ as a yellow solid. Additionally, trichocyalide B and harzianolide were purified by preparative HPLC (column, PEGASIL ODS, $20 \times 250 \mathrm{~mm}$; Senshu Scientific Co.; solvent, $40 \% \mathrm{CH}_{3} \mathrm{CN}$; detection, UV at $210 \mathrm{~nm}$; flow rate, $8.0 \mathrm{ml} \mathrm{min}^{-1}$ ) from the first tube of $50 \% \mathrm{CH}_{3} \mathrm{CN}$ (51.3 mg) with retention times of 18 and $24 \mathrm{~min}$. The pooled peaks were concentrated in vacuo to dryness to give pure trichocyalide B $(6.9 \mathrm{mg})$ and harzianolide $(8.8 \mathrm{mg})$, respectively.

\section{Physicochemical properties}

The physicochemical properties of trichocyalides A and B are summarized in Table 1. On IR spectra, they showed similar absorption maxima at $3440-3444 \mathrm{~cm}^{-1}$ and 1743 or $1745 \mathrm{~cm}^{-1}$, suggesting the presence of hydroxy and furanone ring moieties, respectively. The similarity of their spectral data indicated close structural relationships.

\section{Structures elucidation of trichocyalides A and B}

Trichocyalide A. The molecular formula of trichocyalide A was determined to be $\mathrm{C}_{11} \mathrm{H}_{14} \mathrm{O}_{3}$ on the basis of HREI-MS measurement (Table 1 ). The ${ }^{13} \mathrm{C}$ NMR spectrum (in DMSO- $d_{6}$ ) showed 11 resolved signals, which were classified into one methyl carbon, three $s p^{3}$ methylene carbons, four $s p^{2}$ methine carbons, two quaternary carbons and one carbonyl carbon by analysis of DEPT spectra. The ${ }^{1} \mathrm{H}$ NMR spectrum (in DMSO- $d_{6}$ ) showed one methyl signal, three methylene signals and four methine signals. The connectivity of proton and carbon atoms was established by the HMQC spectrum, as shown in Table 2. Analysis of the ${ }^{1} \mathrm{H}-{ }^{1} \mathrm{H}$ COSY spectrum gave the hexa-2,4-
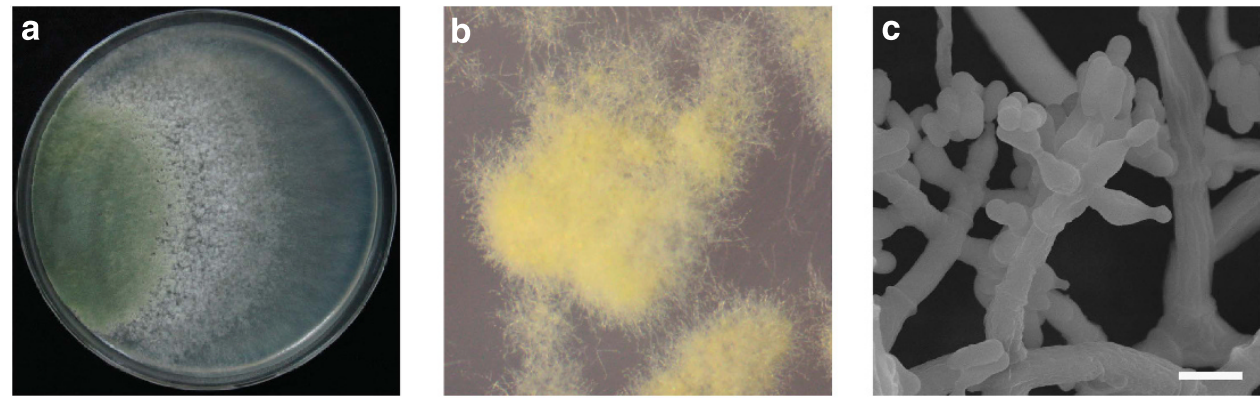

Figure 2 Morphological observation of Trichoderma sp. FKI-5513. (a) Colonies on potato dextrose agar at 7 days. (b) Pustules on synthetic low-nutrient agar at 7 days under a stereoscopic microscope. (c) Conidiophore, under a scanning electron microscope (scale bar: $10 \mu \mathrm{m}$ ). 
diene chain (Figure 3). The ${ }^{1} \mathrm{H}-{ }^{13} \mathrm{C}$ long-range couplings of ${ }^{2} \mathrm{~J}$ and ${ }^{3} \mathrm{~J}$ observed in the $\mathrm{HMBC}$ experiments (Figure 3) gave the following information. The cross peaks from oxymethylene protons $\left(5-\mathrm{H}_{2}\right.$

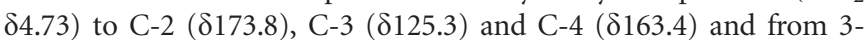
$\mathrm{CH}_{2}$ ( $\left.\delta 4.01\right)$ to $\mathrm{C}-2, \mathrm{C}-3$ and $\mathrm{C}-4$ supported the furane. The cross peaks from $1^{\prime}-\mathrm{H}(\delta 3.29)$ to $\mathrm{C}-3, \mathrm{C}-4$ and $\mathrm{C}-5(\delta 71.1)$ supported that the hexa-2,4-diene chain and furanone ring are conjugated at C-4. From the chemical shift and molecular formula, $3-\mathrm{CH}_{2}$ should have a hydroxyl methyl group. The structure satisfied the molecular formula and degree of unsaturation. From the ${ }^{1} \mathrm{H}$ coupling constants $\left(J_{2^{\prime}, 3^{\prime}}=15.0 \mathrm{~Hz}\right.$ and $\left.J_{4^{\prime}, 5^{\prime}}=15.0 \mathrm{~Hz}\right)$, the diene unit was assigned to both $E$ geometrical configurations. Taken together, the structure of trichocyalide A was elucidated as shown in Figure 1.

Trichocyalide $B$. The molecular formula of trichocyalide $\mathrm{B}$ was determined to be $\mathrm{C}_{11} \mathrm{H}_{16} \mathrm{O}_{3}$ on the basis of HRFAB-MS measurement (Table 1). The differences between trichocyalide $\mathrm{A}$ and trichocyalide $\mathrm{B}$ were the presence of $3-\mathrm{CH}_{3}$ and $(E)$-hex-4-en-1-ol chain for trichocyalide B (Figure 4), from the chemical shifts, ${ }^{1} \mathrm{H}-{ }^{1} \mathrm{H}$ COSY and $\mathrm{HMBC}$ spectra. Cross peaks from $3-\mathrm{CH}_{3}(\delta 1.70)$ to $\mathrm{C}-2(\delta 175.0)$,

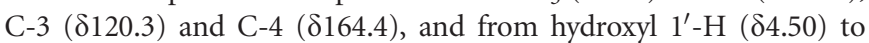

Table 1 Physicochemical properties of trichocyalides A and B

\begin{tabular}{|c|c|c|}
\hline & Trichocyalide $A$ & Trichocyalide $B$ \\
\hline Appearance & yellow solid & yellow solid \\
\hline MW & 194 & 196 \\
\hline Molecular formula & $\mathrm{C}_{11} \mathrm{H}_{14} \mathrm{O}_{3}$ & $\mathrm{C}_{11} \mathrm{H}_{16} \mathrm{O}_{3}$ \\
\hline HR-MS $(m / z)$ & El-MS & FAB-MS \\
\hline Calculated & $194.0943(\mathrm{M})^{+}$ & $197.1178(\mathrm{M}+\mathrm{H})^{+}$ \\
\hline Found & $194.0941(\mathrm{M})^{+}$ & $197.1170(\mathrm{M}+\mathrm{H})^{+}$ \\
\hline UV $\lambda \max _{\operatorname{meOH}} \mathrm{nm}(\varepsilon)$ & 223 (12 100), 336 (970) & 216 (9900), 291(700) \\
\hline$[\alpha]_{D}^{26}$ & - & $+10.2^{\circ}(c=0.1, \mathrm{MeOH})$ \\
\hline \multirow[t]{2}{*}{ IR $v_{\max }^{K B r} \mathrm{~cm}^{-1}$} & $3440,2929,1745,1670$ & $3444,2931,1743,1678$ \\
\hline & $1442,1346,1024,1001$ & $1446,1086,1036$ \\
\hline
\end{tabular}

C-3, C-4 and C-5 (869.5) were observed in the HMBC experiments, confirming that the $3-\mathrm{CH}_{3}$ and $(E)$-hex-4-en-1-ol chain were linked at C-3 and C-4, respectively (Figure 4). The structure satisfied the molecular formula and degree of unsaturation. From the ${ }^{1} \mathrm{H}$ coupling constants $\left(J_{4^{\prime}, 5^{\prime}}=15.0 \mathrm{~Hz}\right)$, the monoene unit was assigned to $E$ geometrical configuration. Taken together, the structure of trichocyalide $\mathrm{B}$ was elucidated as shown in Figure 1.

\section{Biological properties}

Inhibition of ALP activity in osteoblastic C2C12(R206H) cells by trichocyalides. The effects of trichocyalides on ALP activity, a typical marker of osteoblastic differentiation, and on cytotoxicity in C2C12(R206H) cells were tested. As shown in Table 3, trichocyalide A was found to inhibit ALP with an $\mathrm{IC}_{50}$ value of $83.0 \mu \mathrm{M}$ without cytotoxicity even at $500 \mu \mathrm{M}$. On the other hand, trichocyalide B exhibited ALP inhibitory activity and cytotoxicity with $\mathrm{IC}_{50}$ values of 187 and $354 \mu \mathrm{M}$, respectively. Under the same conditions, structurally related herzianolide showed no effect on ALP and cytotoxicity at $500 \mu \mathrm{m}$.

Effect of trichocyalides and herzianolide on BMP signaling. The effect of trichocyalides and herzianolide on BMP signaling was investigated using C2C12(Id1-BRE) cells; ${ }^{14}$ however, trichocyalides showed no effect on luciferase activity even at $500 \mu \mathrm{m}$, indicating that they did not inhibit the early events of BMP signaling. (Table 3 ).

Antimicrobial activity. Only trichocyalide A showed weak antibacterial activity against B. subtilis PCI 219, K. rhizophila ATCC 9341 and

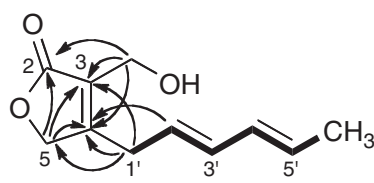

\section{- ${ }^{1} \mathrm{H}-{ }^{-1} \mathrm{H}$ COSY \\ $\frown$ Key $\mathrm{HMBC}$}

Figure 3 Key correlations in ${ }^{1} \mathrm{H}^{1}{ }^{1} \mathrm{H}$ COSY and $\mathrm{HMBC}$ spectra of trichocyalide A.

Table $2{ }^{1} \mathrm{H}$ and ${ }^{13} \mathrm{C}$ NMR chemical shifts of trichocyalides A and B

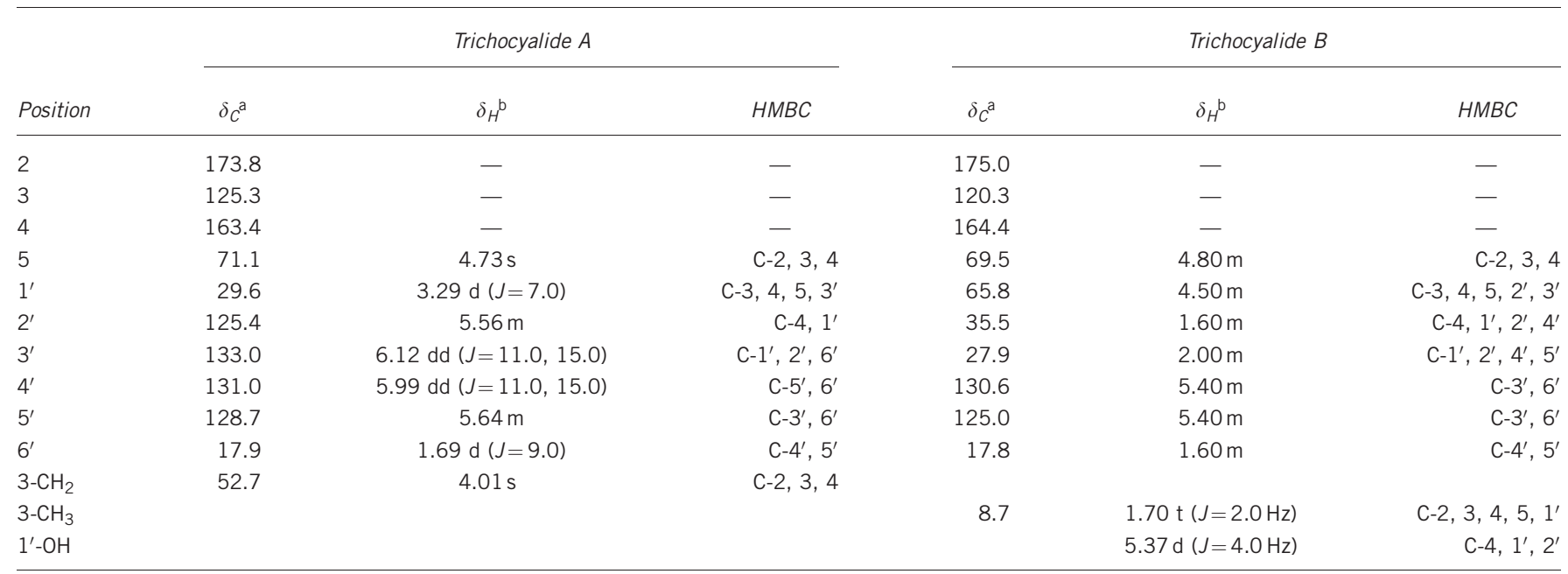

${ }^{a}$ Chemical shifts are shown with reference to DMSO- $d_{6}$ as 39.7 p.p.m.

${ }^{b}$ Chemical shifts are shown with reference to DMSO- $d_{6}$ as 2.49 p.p.m. 


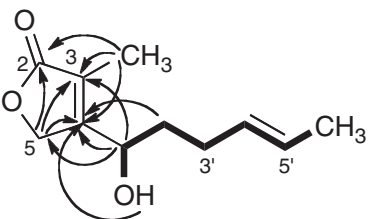

\section{- ${ }^{1} \mathrm{H}-{ }^{-1} \mathrm{H}$ COSY \\ Key $\mathrm{HMBC}$}

Figure 4 Key correlations in ${ }^{1} \mathrm{H}^{-1} \mathrm{H} \quad \mathrm{COSY}$ and $\mathrm{HMBC}$ spectra of trichocyalide B.

Table 3 Effects of trichocyalides A, B and harzianolide on osteoblastic differentiation, cytotoxicity and BMP signaling

\begin{tabular}{lccc}
\hline & \multicolumn{3}{c}{$I C_{50}(\mu \mathrm{m})$} \\
\cline { 2 - 4 } Compounds & $A L P$ & Cytotoxicity & BMP signaling \\
\hline Trichocyalide A & 83.0 & $>500$ & $>500$ \\
Trichocyalide B & 187 & 354 & $>500$ \\
Harzianolide & $>500$ & $>500$ & $>500$ \\
\hline
\end{tabular}

Abbreviations: ALP, alkaline phosphatase; BMP, bone morphogenetic protein.

$X$. campestris $\mathrm{KB} 88$ on conventional paper disk assay (inhibition zone at $10 \mu \mathrm{g}$ per $6 \mathrm{~mm}$ disk: 11,10 and $11 \mathrm{~mm}$, respectively).

\section{DISCUSSION}

The planar structures of trichocyalides $\mathrm{A}$ and $\mathrm{B}$, produced by Trichoderma sp. FKI-5513, were elucidated by spectral analyses. All compounds had the common $\gamma$-butenolactone moiety. Regarding the stereochemistry of $1^{\prime}-\mathrm{OH}$ in trichocyalide $\mathrm{B}$, esterification of trichocyalide B with $S$ - $(+)$-alpha-methoxy-alpha-(trifluoromethyl)phenylacetyl chloride (MTPA-Cl) ${ }^{16}$ yielded two kinds of esters in a ratio of 2:1 (data not shown). Taking into consideration that trichocyalide B showed a positive value of optical rotation $\left(+10.2^{\circ}\right)$, trichocyalide B was suggested to be a mixture of enantiomorphs, not a racemic mixture. Further study will be necessary to define this point.

As described in this study, trichocyalides $\mathrm{A}$ and $\mathrm{B}$ are new potential inhibitors of osteoblastic differentiation. Interestingly, trichocyalides A and $\mathrm{B}$ showed no inhibition of the luciferase activity of Id1WT4F-luc in $\mathrm{C} 2 \mathrm{C} 12$ cells, ${ }^{14}$ suggesting that their target does not lie within early events of Smads ${ }^{9}$ but within late steps, such as p38 or JNK kinase in the BMP signaling pathway. ${ }^{4}$ The target of trichocyalides A and B in osteoblastic differentiation remains to be demonstrated.

\section{METHODS}

\section{General experimental procedures}

UV spectra were recorded on a spectrophotometer (8453 UV-Visible spectrophotometer; Agilent Technologies Inc., Santa Clara, CA, USA). IR spectra were recorded on a Fourier transform infrared spectrometer (FT-710; Horiba Ltd., Kyoto, Japan). Optical rotations were measured with a digital polarimeter (DIP-1000; JASCO, Tokyo, Japan). HREI-MS and HRFAB-MS spectra were recorded on a mass spectrometer (JMS-AX505 HA; JEOL, Tokyo, Japan). Various NMR spectra were measured with a spectrometer (XL-400; Agilent Technologies Inc.),

\section{Materials}

Dulbecco's modified Eagle's medium was purchased from Nacalai Tesque (Kyoto, Japan). Fetal bovine serum was obtained from HyClone (Waltham,
MA, USA). Penicillin/streptomycin was from Invitrogen (Carlsbad, CA, USA). $p$-Nitrophenyl phosphate was purchased from Sigma (St Louis, MO, USA). Recombinant human BMP4 (rhBMP4) was obtained from R\&D Systems (Mountain View, CA, USA).

\section{Taxonomic studies of the producing organism}

Fungal strain FKI-5513 was isolated from soil collected on Hachijo island, Tokyo, Japan. For determination of the morphological characteristics, the isolate was inoculated as a one-point culture on potato dextrose agar, corn meal dextrose agar and synthetic low-nutrient agar, and grown for 7 days at $25^{\circ} \mathrm{C}$ (also at $5^{\circ} \mathrm{C}$ and $37^{\circ} \mathrm{C}$ on potato dextrose agar) in the dark. Color Harmony Manual 4th Edition (Container Corporation of America, Chicago, IL, USA) was used to determine color names and hue numbers. ${ }^{17}$ For the determination of micro-morphological characteristics, the samples were observed under a JSM-5600 scanning electron microscope (JEOL). Genomic DNA of the strain FKI-5513 was isolated using the PrepMan Ultra Sample Preparation Reagent (Applied Biosystems, Foster City, CA, USA) following the manufacturer's instructions. The rDNA ITS including the $5.8 \mathrm{~S}$ rDNA was amplified using primers ITS1 and ITS4. ${ }^{18}$ Amplifications were performed in a PCR Verity 96-well thermal cycler (Applied Biosystems) and the PCR products were purified according to the instructions of the QIAquick PCR DNA purification kit protocol (Qiagen, Inc., Valencia, CA, USA). The PCR products were sequenced directly in both directions using primers (ITS1, ITS2, ITS3 and ITS4) and a BigDye Terminator v3.1 Cycle Sequencing Kit (Applied Biosystems). Sequencing products were purified by ethanol/EDTA precipitation, and samples were analyzed on an ABI PRISM 3130 Genetic Analyzer (Applied Biosystems). Contigs were assembled using forward and reverse sequences with the SeqMan and SeqBuilder programs from the Lasergene8 package (DNAStar Inc., Madison, WI, USA). The ITS sequence of the strain was deposited in the DNA Data Bank of Japan (DDBJ) with accession number AB606411.

\section{Cell culture}

A C2C12 myoblasts cell line and C2C12(R206H) cell line, ${ }^{19}$ which exhibited ALP activity more quickly and more strongly than the original C2C12 cell line, were cultured in Dulbecco's modified Eagle's medium supplemented with $15 \%$ fetal bovine serum and 100 units $\mathrm{ml}^{-1}$ penicillin and $100 \mu \mathrm{gm}^{-1}$ streptomycin (hereafter referred to as medium A) at $37^{\circ} \mathrm{C}$ in $5.0 \% \mathrm{CO}_{2}$. Both cells were subcultured once every three days.

\section{Assay for ALP in BMP-treated C2C12(R206H) cells}

ALP activity, a typical marker of osteoblastic differentiation, was measured as described previously. ${ }^{14}$ In brief, C2C12(R206H) cells $\left(7.5 \times 10^{3}\right.$ cells per well) in a 96-well plastic plate were cultured at $37^{\circ} \mathrm{C}$ in $5.0 \% \mathrm{CO}_{2}$. Following overnight recovery, the culture media were replaced with $100 \mu \mathrm{l}$ fresh medium A containing $\operatorname{rhBMP} 4\left(10 \mathrm{ng} \mathrm{ml}^{-1}\right)$ and a sample $(1 \mu \mathrm{l}$ in $\mathrm{MeOH}$ solution). After 48-h incubation, the cells were incubated for $60 \mathrm{~min}$ with $100 \mu \mathrm{l}$ substrate solution ( $100 \mathrm{~mm}$ diethanolamine, $0.5 \mathrm{mM} \mathrm{MgCl}_{2}$ and $1.0 \mathrm{mg} \mathrm{ml}^{-1}$ $p$-nitrophenylphosphate) at room temperature. The reaction was terminated by adding $50 \mu \mathrm{l}$ of $3 \mathrm{M} \mathrm{NaOH}$, and the absorbance at $405 \mathrm{~nm}$ was measured with a Power Wave $\times 340($ BIO-TEK Instruments, Highland Park, IL, USA).

\section{Cytotoxicity}

The cytotoxicity of a compound to $\mathrm{C} 2 \mathrm{C} 12(\mathrm{R} 206 \mathrm{H})$ cells was evaluated by the 3-(4,5-dimethylthiazol-2-yl)-2,5-diphenyl tetrazolium (MTT) assay. ${ }^{20}$ In brief, $\mathrm{C} 2 \mathrm{C} 12(\mathrm{R} 206 \mathrm{H})$ cells $\left(7.5 \times 10^{3}\right.$ cells per well $)$ were cultured in 96-well plates in the absence or presence of a compound for $48 \mathrm{~h}$ at $37^{\circ} \mathrm{C}$ in $5 \% \mathrm{CO}_{2}$. After incubation, the cells received $10 \mu \mathrm{l}$ MTT solution $\left(5.5 \mathrm{mg} \mathrm{ml}^{-1}\right.$ in phosphatebuffered saline), and were then incubated at $37^{\circ} \mathrm{C}$ for $3 \mathrm{~h}$. A $90 \mu \mathrm{l}$ aliquot of the lysis solution ( $40 \% \mathrm{~N}, \mathrm{~N}$-dimethylformamide, $2.0 \% \mathrm{CH}_{3} \mathrm{COOH}, 20 \% \mathrm{SDS}$ and $0.03 \mathrm{M} \mathrm{HCl}$ ) was added to each well, and the plates were incubated for $2 \mathrm{~h}$. The absorbance at $550 \mathrm{~nm}$ of each well was read with a Power Wave $\times 340$. Inhibition of cell growth is defined as (absorbance-sample/absorbancecontrol $) \times 100$. The $\mathrm{IC}_{50}$ value is defined as a sample concentration that causes $50 \%$ inhibition of cell growth. 
Reporter gene assay for monitoring BMP signaling

Recently, a unique mutation, $\mathrm{R} 206 \mathrm{H}$, in the $A L K 2$ gene was suggested to induce FOP by activating BMP signaling using a constitutively activated BMP type I receptor, ${ }^{5}$ indicating that BMP signaling was one of the targets of FOP treatment. ${ }^{6}$ The effect of a compound on BMP signaling via Smads (early events in BMP signaling) was examined using a BMP-specific luciferase reporter, Id1WT4F-luc, which is driven by four tandem copies of BRE in the $\mathrm{Id} 1$ gene. ${ }^{4}$ In brief, $\mathrm{C} 2 \mathrm{C} 12$ cells were inoculated at $1.0 \times 10^{4}$ cells per well in 96-well plates with medium A and incubated for $24 \mathrm{~h}$. The cells were transfected with $200 \mathrm{ng}$ plasmid DNA (40 ng Id1WT4F-luc, $10 \mathrm{ng}$ phRL-SV40 and $150 \mathrm{ng}$ ALK2(R206H)) using $0.5 \mu \mathrm{l}$ Lipofectamine 2000 (Invitrogen) in OPTI-MEM (GIBCO, Grand Island, NY, USA) according to the manufacturer's protocol. After 2.5-h incubation, the culture medium was replaced with $100 \mu \mathrm{l}$ fresh Dulbecco's modified Eagle's medium containing 2.5\% fetal bovine serum without penicillin/streptomycin. After an additional 3-h incubation, a compound ( $1 \mu \mathrm{l}$ methanol solution) was added to each well and cultured for $24 \mathrm{~h}$. Both firefly and Renilla luciferase activities in the cells were determined using the Dual Glo Luciferase assay system (Promega, Madison, WI, USA).

\section{Antimicrobial activity}

Antimicrobial activity against 14 species of microorganisms was measured by our established method ${ }^{21}$ using Bacillus subtilis PCI 219, Staphylococcus aureus FDA 209P, Kocuria rhizophila ATCC 9341, Mycobacterium smegmatis ATCC 607, Escherichia coli NIHJ, Pseudomonas aeruginosa P-3, Xanthomonas campestris pv. Oryzae KB 88, Bacteroides fragilis ATCC 23745, Acholeplasma laidlawii PG 8, Pyricularia oryzae KF 180, Aspergillus niger ATCC 6275, Mucor racemosus IFO 4581, Candida albicans ATCC 64548 and Saccharomyces cerevisiae. GAM agar (Nissui Seiyaku Co., Tokyo, Japan) for B. fragilis; Bacto PPLO agar (Sanko Junyaku Co. Ltd., Tokyo, Japan) supplemented with $15 \%$ horse serum, $0.1 \%$ glucose, $0.25 \%$ phenol red $\left(5 \mathrm{mg} \mathrm{ml}^{-1}\right)$ and $1.5 \%$ agar for A. laidlawii; Taiyo agar (Shimizu Syokuhin Kaisya Ltd., Shizuoka, Japan) for the other bacteria; a medium composed of $1.0 \%$ glucose, $0.5 \%$ yeast extract and $0.8 \%$ agar for fungi and yeasts. A paper disk (i.d. $6 \mathrm{~mm}$; Toyo Roshi Kaisha Ltd., Tokyo, Japan) containing a $10 \mu \mathrm{g}$ sample was placed on an agar plate. Bacteria, with the exception of $X$. oryzae, were incubated at $37^{\circ} \mathrm{C}$ for $24 \mathrm{~h}$. Yeasts and $X$. oryzae were incubated at $27^{\circ} \mathrm{C}$ for $24 \mathrm{~h}$. Fungi were incubated at $27^{\circ} \mathrm{C}$ for $48 \mathrm{~h}$. Antimicrobial activity was expressed as the diameter (mm) of the inhibitory zone.

\section{ACKNOWLEDGEMENTS}

We wish to thank Dr K Nagai and Ms N Sato (Kitasato University) for measurements of mass and NMR spectra, respectively.
1 Luyten, F. P. et al. Purification and partial amino acid sequence of osteogenin, a protein initiating bone differentiation. J. Biol. Chem. 264, 13377-13380 (1989).

2 Wozney, J. M. et al. Novel regulators of bone formation: molecular clones and activities. Science 242, 1528-1534 (1988).

3 Macías-Silva, M., Hoodless, P. A., Tang, S. J., Buchwald, M. \& Wrana, J. L. Specific activation of Smad1 signaling pathways by the BMP7 type I receptor, ALK2. J. Biol. Chem. 273, 25628-25636 (1998).

4 Katagiri, T. et al. Identification of a BMP-responsive element in Id1, the gene for inhibition of myogenesis. Genes Cells 7, 949-960 (2002).

5 Peltier, L. F. A case of extraordinary exostoses on the back of a boy. 1740. John Freke. Clin. Orthop. Relat. Res. 346, 5-6 (1998).

6 Kaplan, F. S. et al. Genetic transmission of fibrodysplasia ossificans progressiva. Report of a family. J. Bone. Joint. Surg. Am. 75, 1214-1220 (1993).

7 Glaser, D. L. et al. In vivo somatic cell gene transfer of an engineered Noggin mutein prevents BMP4-induced heterotopic ossification. J. Bone Joint Surg. Am. 85, 2332-2342 (2003).

8 Shore, E. M. et al. A recurrent mutation in the BMP type I receptor ACVR1 causes inherited and sporadic fibrodysplasia ossificans progressiva. Nat. Genet. 38, 525-527 (2006).

9 Katagiri, T. Heterotopic bone formation induced by bone morphogenetic protein signaling: fibrodysplasia ossificans progressiva. J. Oral. Biosci. 52, 33-41 (2010).

10 Katagiri, T. et al. Bone morphogenetic protein-2 converts the differentiation pathway of C2C12 myoblasts into the osteoblast lineage. J. Cell Biol. 127, 1755-1766 (1994).

11 Fukuda, T. et al. Fungal pyrrolidine-containing metabolites inhibit alkaline phosphatase activity in bone morphogenetic protein-stimulated myoblastoma cells. Acta Pharmaceutica Sinica B 2, 23-27 (2012).

12 Kakeya, $\mathrm{H}$. et al. Lucilactaene, a new cell cycle inhibitor in p53-transfected cancer cells, produced by a Fusarium sp. J. Antibiot. 54, 850-854 (2001).

13 Bashyal, B. P., Faeth, S. H. \& Gunatilaka, A. A. 13a-Hydroxylucilactaene and other metabolites of an endophytic strain of fusarium acuminatum. Nat. Prod. Commun. 2, 547-550 (2007).

14 Bashyal, B. P. \& Gunatilaka, A. A. Tricinonoic acid and tricindiol, two new irregular sesquiterpenes from an endophytic strain of Fusarium tricinctum. Nat. Prod. Res. 24, 349-356 (2010)

15 Norman, C., James, R. H., Almaz, T. \& Anthony, G. A. Harzianolide, a butenolide metabolite from cultures of Trichoderma harzianum. Pytochemistry 30, 3802-3803 (1991).

16 Ohtani, I., Kusumi, T., Kashman, Y. \& Kakisawa, H. High-field FT NMR application of Mosher's method. The absolute configuration of marine terpenoids. J. Am. Chem. Soc. 113, 4092-4096 (1991)

17 Jacobson, E., Granville, W. C. \& Foss, C. E. Color Harmony Manual. 4th ed. (Container of America, Chicago, 1958).

18 White, T. J., Bruns, T., Lee, S. \& Taylor, J. W. Amplification and direct sequencing of fungal ribosomal RNA genes for phylogenetics. in PCR Protocols a Guide to Methods and Applications (eds Innis, M. A., Gelfand, R. H., Sninsky, J. J. \& White, T. J.) 315-332 (Academic Press, New York, 1990).

19 Fukuda, T. et al. Constitutively activated ALK2 and increased SMAD1/5 cooperatively induce bone morphogenetic protein signaling in fibrodysplasia ossificans progressiva. J. Biol. Chem. 284, 7149-7156 (2009).

20 Mosmann, T. Rapid colorimetric assay for cellular growth and survival: application to proliferation and cytotoxicity assays. J. Immunol. Methods 65, 55-63 (1983).

21 Fukuda, T. Matsumoto, A., Takahashi, Y., Tomoda, H. \& Ōmura, S. Phenatic acids A and $\mathrm{B}$, new potentiators of antifungal miconazole activity produced by Streptomyces sp. K03-0132. J. Antibiot. 58, 252-259 (2005). 